\title{
OLIGOCENE WHALES AND DOLPHINS FROM THE SOUTHWEST PACIFIC
}

FORDYCE, R. Ewan, Dept. of Geology, University of Otago, P.O. Box 56, Dunedin, New Zealand

Shelf strata of southern New Zealand preserve diverse assemblages of later Paleogene Cetacea. These provide early records for many taxa, and elucidate the explosive early radiation of the extant groups Odontoceti (toothed whales and dolphins) and Mysticeti (baleen whales).

Most specimens are partial skeletons from thin greensand and limestone overlying a $\sim 30$ Ma unconformity in the Waitaki Valley region. Invertebrates provide biostratigraphic control of the local upper Whaingaroan, Duntroonian and Waitakian Stages, roughly late Oligocene to earliest Miocene. Associated Oligocene vertebrates include penguins, chondrichthyans, and teleosts, but no sea turtles, pinnipeds, sirenians or desmostylians. Faunas and sediment character indicate quiet mid to outer shelf depths in a sheltered setting.

Work since 1982 has greatly expanded the previously-described fauna of 14 named species of Archaeoceti, Odontoceti, and Mysticeti, and has significantly revised previous family-level determinations. Most of the new species are from the Duntroonian and lower Waitakian stages. Archaeocetes occur in the Eocene but not in younger strata. Rare archaic toothed mysticetes include species of Kekenodontidae, Mammalodontidae, and problematica. Baleen-bearing whales include Mauicetus-like species previously referred to the paraphyletic and polyphyletic family Cetotheriidae. Other species of Mauicetus (sensu Marples) probably belong with new material in a new higher clade of baleen-bearing mysticetes. Aetiocetidae are notably absent. Odontocetes mostly belong in the Platanistoidea, a clade diverse in the Oligocene but now represented by only 2 extant freshwater species; notable are species of Squalodontidae, Waipatiidae, Squalodelphidae and Dalpiazinidae. Archaic true dolphins (Kentriodontidae and problematica), sperm whales (Physeteridae) and Eurhinodelphidae are rare. Notable absences include archaic odontocetes such as Agorophiidae and the Xenorophus group, and beaked whales (Ziphiidae).

Larger mysticetes dominate assemblages, with small odontocetes also conspicuous. The shallow broad seaway could have been a breeding ground for mysticetes, which might thus represent a recently developed southern ocean ecosystem south of New Zealand. Perhaps the shallow seaway was only rarely inhabited by more oceanic or deep-diving species of delphinoids and sperm whales.

The assemblages reinforce the idea that the Oligocene was a time of structural/ ecological experiment. Species were scattered more evenly amongst diverse familylevel taxa. In contrast, for extant cetaceans, a few families account for most of the species diversity.

Some of the better-preserved fossils will help resolve cladistic relationships of extant Cetacea, thus providing an independent standard against which to compare molecular classifications. Revised classifications should also help quantitative zoogeography. Meanwhile, non-quantitative comparisons suggest a faunal composition more similar to that of the Caucasus than of the Atlantic Coastal Plain or northeast Pacific. Only archaic toothed mysticetes hint at trans-Pacific links. 